\title{
sciendo
}

\section{EDITORIAL 2019: CONTINUATION OF PROMOTION AND NEW EFFORTS}

\author{
Tea Tomljanović* , Daniel Matulić \\ University of Zagreb, Faculty of Agriculture, Svetošimunska cesta 25, 10000 Zagreb, Croatia \\ *Corresponding Author, Email: ttomljanovic@agr.hr
}

\section{ARTICLE INFO}

Keywords:

Promotion

Croat J Fish

Open Access

How to Cite

\section{ABSTRACT}

Croat J Fish continues in its effort to stay an important scientific and professional journal in the region. In this year, the Journal was advanced by new Editorial Board members while cooperation with SCIENDO publishers has been extended until the end of 2020. We hope and expect 2019 to be yet another significant year in fisheries science and we look forward to sharing it with you. The Editorial also provides information on the latest news on Open Access Journals Initiative, the Journal Scopus CiteScore metrics, as well as the articles published in Croat J Fish in 2018, with a list of reviewers who participated in the review process.

Tomljanović, T., Matulić, D. (2019): Editorial 2019: Continuation of promotion and new efforts. Croatian Journal of Fisheries, 77, 1-6. DOI: 10.2478/cjf-2019-0001

\section{EDITORIAL PRACTICES AND JOURNAL PROMOTION}

It is important to constantly strive to improve our scientific journal, so participation in conferences through which we gain knowledge about scientific research publishing and promoting the Journal is essential. Croat J Fish attended the 5th PUBMET2018 conference which was held in Zadar, Croatia on 20-21 September 2018 (Fig. 1). The themes of the conference were mostly focused on openness (open science, open data, open scholarly communication, open repositories, open peer review), publication and editorial practices, authorship and copyright, plagiarism and ethical issues, advances in digital scholarly publishing, bibliometrics, altmetrics, with the aim of bringing together a diverse community of researchers, university teachers, publishers, editors, librarians/information specialists, policy-makers, as well as experts from other fields of research and development. Also, there was discussion on development, current trends and accepted standards of scientific publishing, which is one of the basic prerequisites for the advancement and development of European and world scientific journals. The conference

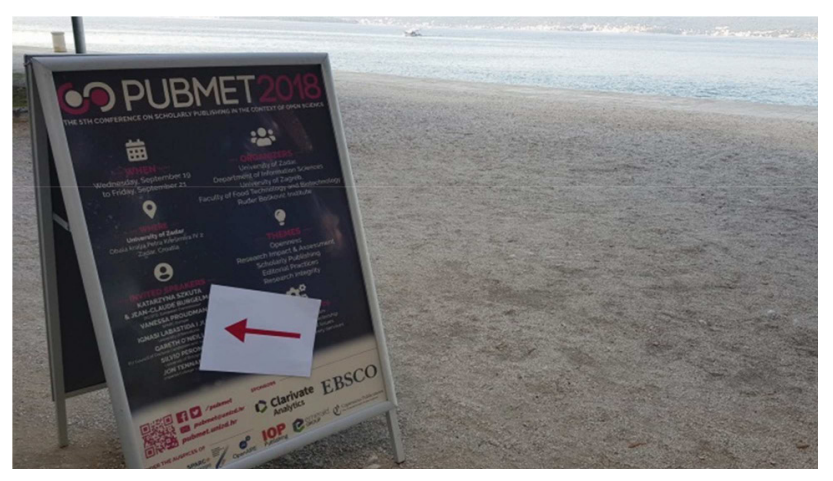

Fig 1. Announcement and signpost for the 5th PUBMET2018 conference in Zadar, Croatia

organizers were the University of Zagreb, Faculty of Food Technology and Biotechnology, University of Zadar, Department of Information Sciences and Ruđer Bošković Institute.

Croat J Fish was one of the media sponsors of VIII International Conference WATER\&FISH 2018 held in Belgrade, Serbia on 13 - 15 June 2018 (Fig. 2). The conference was organized by the Faculty of Agriculture, University of Belgrade, Serbia and International Aquatic 


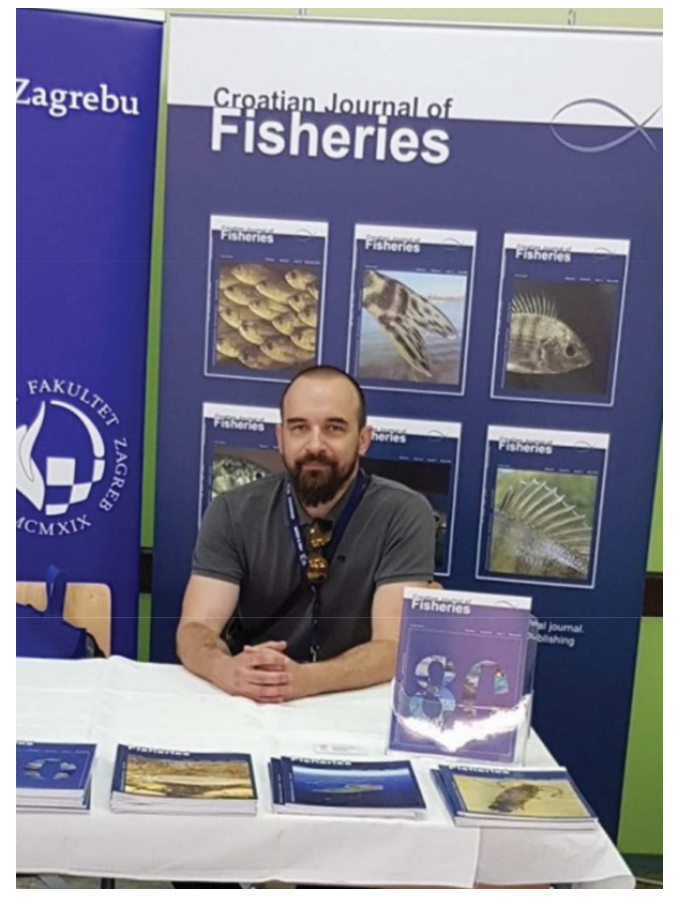

Fig 2. Croatian Journal of Fisheries as a media sponsor of the VIII International Conference WATER\&FISH 2018 in Belgrade, Serbia (presented in the photo is Editor-in-Chief, D. Matulić)

Veterinary Biosecurity Consortium, Faculty of Veterinary Medicine, Ludwig-Maximilians- University Munich, Germany, and supported by The European Aquaculture Society (EAS). It was a great opportunity to present the Journal to the regional scene, resulting in an increase of the number of manuscripts from this part of the world.

European Association of Science Editors organized a conference Balancing innovation and tradition in science editing in Bucharest, Romania between 8 and 10 June 2018 (Fig. 3). During the conference, delegates had the opportunity to hear about the latest developments in science publishing, including topics such as innovations in journal publishing, sex and gender equity in research, reducing waste in research and data citation. Other sessions were focused on editing a journal, addressing topics such as local language vs. English language, ways to improve a journal and managing peer review. There were also series of workshops covering statistics, plagiarism and publishing ethics. A representative of the Editorial Board of Croat J Fish, Tea Tomljanović, attended the conference.

\section{cOAlition $S$ for the realisation of full and immediate Open Access}

Due to accelerating the transition to full and immediate Open Access to scientific publications, 11 national research funding organisation, with the support of the European Commission including the European Research Council (ERC), are announcing the launch of cOAlition $\mathrm{S}$, an initiative to make full and immediate Open Access to research publications a reality. cOAlition $S$ signals

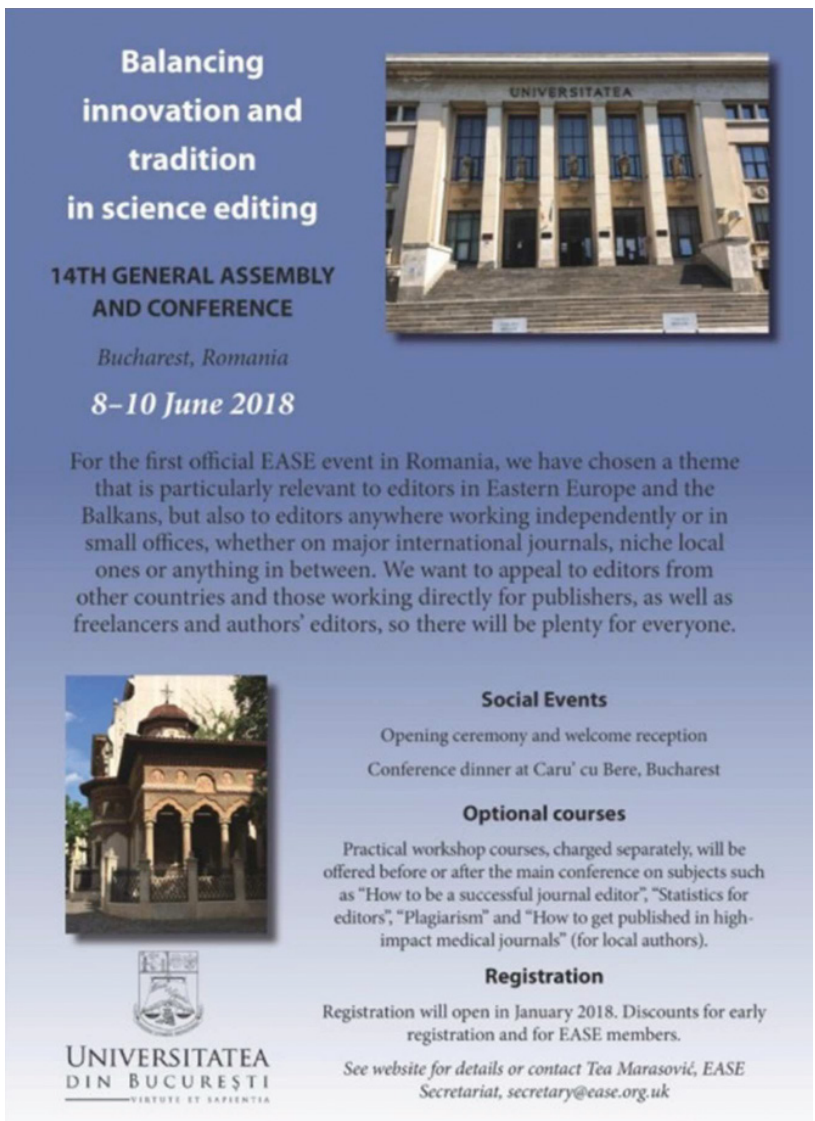

Fig 3. Announcement of the conference Balancing innovation and tradition in science editing in Bucharest, Romania

the commitment to implement, by 1 January 2020, the necessary measures to fulfil its main principle: "After 1 January 2020 scientific publications on the results from research funded by public grants provided by national and European research councils and funding bodies must be published in compliance with Open Access Journals or in compliance with Open Access Platforms" (Schiltz, 2018).

\section{NEW EDITORIAL MEMBERS}

We are pleased to introduce the new members of the Croat J Fish Editorial Board. Our new Editorial members are Jacopo Aguzzi, Luca Camanzi, Alexis Conides, Yeamin Hossain and Sanja Matić Skoko. We are grateful to all of our Editorial Board members for their contribution to Croat J Fish and service to the scientific community.

\section{SCOPUS CiteScore METRICS}

According to SCOPUS CiteScore metrics, which measures average citations received per document published in the serial, Croat J Fish average number of citations received per document published in the serial for 2017 was 0.8 . SClmago Journal Rank (SJR) which measures weighted citations received by the serial for 2017 was 0.3 . Citation 
Table 1. Topics covered by the Croatian Journal of Fisheries and titles of published papers in 2018 (Original scientific paper - OS; Review article - RA; Short communication - SC; Supplement to fishing profession - SFP)

\begin{tabular}{cccc}
\hline \hline $\begin{array}{c}\text { MAIN SUBJECT } \\
\text { CATEGORY }\end{array}$ & PAPER TITLE & PEER & REFERENCES \\
& & REVIEW & TyPe of \\
\end{tabular}

Behavioral observations of the endangered Rio Grande silvery minnow in a conservation aquaculture facility

The effect of seasonal temperature on endogenous gut enzyme activity in four air-breathing fish species

Freshwater

Aquaculture
Yes

Tave et al., 2018

OS

Yes

Banerjee et al., 2018

OS

Yes

Ivšić et al., 2018

OS

Effects of dietary Moringa oleifera leaf as a replacement of soybean meal on growth, body composition and health status in Cyprinus carpio juveniles

Life history traits of Neretva roach Rutilus basak (Heckel, 1843) (Pisces, Cyprinidae): Biological- ecological contribution for biodiversity conservation of freshwater fish

Yes Tutman et al., 2018

RA

The effects of two different preservation methods on morphological characteristics of the alien channel catfish Ictalurus punctatus (Rafinesque, 1818) in European freshwater

Ichthyology

Variability of otolith morphology and morphometry in eight juvenile fish species in the coastal eastern Adriatic

Yes

Ferri et al., 2018

OS

Phototactic response and morphometric characteristic of climbing perch Anabas testudineus (Bloch, 1792) under culture system

Yes $\quad$ Ahmadi, 2018

OS

Body pigmentation and meristic characteristics of Balkan golden loach (Sabanejewia balcanica) from the water catchment area of the river Sava

Yes Haubrock et al., 2018

SC
The occurrence of royal flagfin Aulopus filamentosus (Bloch, 1792) in Mersin bay (North - Eastern Mediterranean) Turkey

Diet composition and trophic level of greater forkbeard Phycis blennoides (Gadiform: Phycidae) from the Algerian coast

Yes

Alioua et al., 2018

OS

A review of the marine crab fisheries in the Turkish Seas

Yes Harlığlu et al., 2018

RA

Impact of water level fluctuation in the shaping of zooplankton assemblage in a shallow lake

Yes Špoljar et al., 2018

OS

Inland water

First record of Azygia robusta (Odhner, 1911) (Trematoda: Digenea: Azygiidae) in brown trout (Salmo trutta) in the Vrbas River 


\begin{tabular}{|c|c|c|c|c|}
\hline $\begin{array}{l}\text { MAIN SUBJECT } \\
\text { CATEGORY }\end{array}$ & PAPER TITLE & $\begin{array}{l}\text { PEER } \\
\text { REVIEW }\end{array}$ & REFERENCES & $\begin{array}{l}\text { Type of } \\
\text { article }\end{array}$ \\
\hline \multirow{3}{*}{ Genetics } & $\begin{array}{l}\text { Microsatellite analysis of golden grey mullet Chelon auratus } \\
\text { (Risso, 1810) in the Fereydoon- Kenar and Ramsar coasts (south } \\
\text { Caspian Sea, Iran) }\end{array}$ & Yes & Behrouz et al., 2018 & OS \\
\hline & $\begin{array}{l}\text { Evaluation of genetic damage in Oreochromis mossambicus } \\
\text { exposed to selected nanoparticles by using micronucleus and } \\
\text { comet bioassays }\end{array}$ & Yes & $\begin{array}{l}\text { Vidya and Chitra } \\
2018\end{array}$ & OS \\
\hline & $\begin{array}{l}\text { A new species of mullet, Chelon caeruleum (Family: Mugilidae), } \\
\text { with description of its genetic relationship to some Mugilids }\end{array}$ & Yes & Deef, 2018 & OS \\
\hline \multirow{3}{*}{ Economy } & $\begin{array}{l}\text { Common Fisheries Policy and its impact on the fisheries sector } \\
\text { in Croatia }\end{array}$ & Yes & Mikuš et al., 2018 & RA \\
\hline & $\begin{array}{l}\text { Economic and social impact of marine sport and recreational } \\
\text { fisheries in Croatia }\end{array}$ & Yes & Soldo et al., 2018 & OS \\
\hline & $\begin{array}{l}\text { Impact assessment of EU funds on company's performance in } \\
\text { the fish processing industry: The case of Croatia. }\end{array}$ & Yes & Božanić, 2018 & OS \\
\hline $\begin{array}{l}\text { Supplement to } \\
\text { fishing profession }\end{array}$ & $\begin{array}{l}\text { EIFAAC International Symposium and 29th Session in Stare } \\
\text { Jablonki, Poland, 6-8 September } 2017\end{array}$ & No & Piria, 2018 & SFP \\
\hline Editorial & $\begin{array}{l}\text { EDITORIAL 2018: The Croatian Journal of Fisheries: Ribarstvo } \\
\text { 80th Anniversary }\end{array}$ & No & $\begin{array}{l}\text { Matulić and } \\
\text { Tomljanović, } 2018\end{array}$ & \\
\hline
\end{tabular}

weighting depends on the subject field and prestige of the citing serial. Source Normalized Impact per Paper (SNIP) which measures actual citations received relative to citations expected for the serial's subject field SNIP for Croat J Fish was 0.687.

\section{Abstracting and indexing}

Croat J Fish is still covered by the following services: AGRICOLA (National Agricultural Library), AGRIS, Baidu Scholar, Cabell's Directory, CABI (over 50 subsections), Clarivate Analytics - BIOSIS Previews, Clarivate Analytics - Web of Science, Clarivate Analytics - Zoological Record, CNKI Scholar (China National Knowledge Infrastructure), CNPIEC, DOAJ (Directory of Open Access Journals), EBSCO (relevant databases), EBSCO Discovery Service, Elsevier - SCOPUS, Google Scholar, Hrčak, Japan Science and Technology Agency (JST), J-Gate, JournalTOCs, KESLINDSL (Korean National Discovery for Science Leaders), Microsoft Academic, Naviga (Softweco), Primo Central (ExLibris), ProQuest (relevant databases), Publons, ReadCube, SCImago (SJR), Summon (Serials Solutions/ ProQuest), TDNet, Ulrich's Periodicals Directory/ ulrichsweb, WanFang Dana and WorldCat (OCLC).

\section{ISSUES IN 2018}

In 2018, 13 original scientific papers, 4 short communications, 3 review papers, one supplement to fishing profession and one Editorial paper were published. The manuscripts covered topics in freshwater aquaculture and inland waters freshwater aquaculture, marine biology, inland water, ichthyology, genetics and economy in fisheries (Table 1). A total of 73 manuscript submissions were received in 2018.

\section{SAŽETAK}

\section{UVODNIK 2019: NASTAVAK PROMOCIJE I NOVA NASTOJANJA}

Croat J Fish nastavlja svoja nastojanja da ostane važan znanstveni i stručni časopis u regiji. U ovoj godini časopis je unaprijeđen uvođenjem novih članova uredništva, a suradnja sa suizdavačem SCIENDO produžena je do kraja 2020. godine. Nadamo se i očekujemo da će 
2019. godina biti još jedna značajna godina u ribarskoj znanosti i radujemo se što ćemo je podijeliti s vama. Uvodnik također pruža informacije o najnovijim vijestima o inicijativama časopisa otvorenog pristupa, metodi vrednovanja časopisa Journal Scopus CiteScore, kao i pregled članaka objavljenih u Croat J Fish u 2018. godini, $\mathrm{s}$ popisom recenzenata koji su sudjelovali u procesu recenzije radova.

Ključne riječi: promocija, Croat J Fish, otvoreni pristup

\section{REFERENCES}

Adeshina, I., Sani, R.A., Adewale, Y.A., Tiamiyu, L.O., Umma, S.B. (2018): Effects of dietary Moringa oleifera leaf as a replacement of soybean meal on growth, body composition and health status in Cyprinus carpio juveniles. Croatian Journal of Fisheries, 76, 174-182.

Ahmadi, A. (2018): Phototactic response and morphometric characteristic of climbing perch Anabas testudineus (Bloch, 1792) under culture system. Croatian Journal of Fisheries, 76, 164-173.

Alioua, Z., Amira, S., Derbal, F., Rachedi, M., Bahbah, L., Bensari, B., Zerouali-Khodja, F. (2018): Diet composition and trophic level of greater forkbeard Phycis blennoides (Gadiform: Phycidae) from the Algerian coast. Croatian Journal of Fisheries, 76, 135-144.

Bajrić, A., Adrović, A., Hajdarević, E., Skenderović, I., Tanović, E. (2018): Body pigmentation and meristic characteristics of Balkan golden loach (Sabanejewia balcanica) from the water catchment area of the river Sava. Croatian Journal of Fisheries, 76, 72-79.

Banerjee, G., Ray, A.K. (2018): The effect of seasonal temperature on endogenous gut enzyme activity in four air-breathing fish species. Croatian Journal of Fisheries, 76, 60-65.

Behrouz, M., Norouzi, M., Samiei, M. H., Heshmatzad, P. (2018): Microsatellite analysis of golden grey mullet Chelon auratus (Risso, 1810) in the Fereydoon-Kenar and Ramsar coasts (south Caspian Sea, Iran). Croatian Journal of Fisheries, 76, 35-40.

Božanić, K. (2018): Impact assessment of EU funds on company's performance in the fish processing industry: The case of Croatia. Croatian Journal of Fisheries, 76, 145-153.

Deef, L.E.M. (2018): A new species of mullet, Chelon caeruleum (Family: Mugilidae), with description of its genetic relationship to some Mugilids. Croatian Journal of Fisheries, 76, 107-114.

Erguden, D., Bayhan, Y. K., Erguden, S. A., Altun, A. (2018): The occurrence of royal flagfin Aulopus filamentosus (Bloch, 1792) in Mersin bay (North - Eastern Mediterranean) Turkey. Croatian Journal of Fisheries, 76, 51-54.

Ferri, J., Bartulin, K., Škeljo, F. (2018): Variability of otolith morphology and morphometry in eight juvenile fish species in the coastal eastern Adriatic. Croatian Journal of Fisheries, 76, 91-98.

Harlıoğlu, M.M., Farhadi, A., Ateş, A.S. (2018): A review of the marine crab fisheries in the Turkish Seas. Croatian Journal of Fisheries, 76, 124-134.

Haubrock, P.J., Balzani, P., Johović, I., Inghilesi, A.F., Tricarico, E. (2018): The effects of two different preservation methods on morphological characteristics of the alien channel catfish Ictalurus punctatus (Rafinesque, 1818) in European freshwater. Croatian Journal of Fisheries, 76, 80-84.

Ivšić, M., Kovačević, G. (2018): Evaluation of algae farming using the Chlorella bioassay. Croatian Journal of Fisheries, 76, 99-106.

Matulić, D., Tomljanović, T. (2018): Editorial 2018: The Croatian Journal of Fisheries: Ribarstvo 80th Anniversary. Croatian Journal of Fisheries, 76, 1-6.

Mikuš, O., Zrakić, M., Kovačićek, T., Jež Rogelj, M. (2018): Common Fisheries Policy and its impact on the fisheries sector in Croatia. Croatian Journal of Fisheries, 76, 4150.

Nikolić, V., Bilbija, B., Nedić, Z., Simonović, P., Djikanović, V. (2018): First record of Azygia robusta (Odhner, 1911) (Trematoda: Digenea: Azygiidae) in brown trout (Salmo trutta) in the Vrbas River. Croatian Journal of Fisheries, 76, 85-88.

Piria, M. (2018): EIFAAC International Symposium and 29th Session in Stare Jablonki, Poland, 6-8- September 2017. Croatian Journal of Fisheries, 76, 55-57.

Schiltz, M. (2018): Science without publication paywalls: cOAlition $S$ for the realisation of full and immediate Open Access. PLoS Biol, 16, 9, 1-4.

Soldo, A., Fredotović, M., Šaran, A., Slišković, M., Mihanović, V., Jelić Mrčelić, G. (2018): Economic and social impact of marine sport and recreational fisheries in Croatia. Croatian Journal of Fisheries, 76, 154-163.

Špoljar, M., Dražina, T., Lajtner, L., Kovačević, G., Pestić, A., Matijašec, D., Tomljanović, T. (2018): Impact of water level fluctuation in the shaping of zooplankton assemblage in a shallow lake. Croatian Journal of Fisheries, 76, 27-34.

Tave, D., Toya, A. L., Hutson, M. A. (2018): Behavioral observations of the endangered Rio Grande silvery minnow in a conservation aquaculture facility. Croatian Journal of Fisheries, 76, 7-26.

Tutman, P., Matić-Skoko, S., Hamzić, A., Dulčić, J., Glamuzina, B. (2018): Life history traits of Neretva roach Rutilus basak (Heckel, 1843) (Pisces, Cyprinidae): Biological-ecological contribution for biodiversity conservation of freshwater fish. Croatian Journal of Fisheries, 76, 66-71.

Vidya, P.V., Chitra, K.C. (2018): Evaluation of genetic damage in Oreochromis mossambicus exposed to selected nanoparticles by using micronucleus and comet bioassays. Croatian Journal of Fisheries, 76, 115124. 
Appendix 1. List of reviewers* for the Croatian Journal of Fisheries between 1 January 2018 and 31 December 2018 (*list of reviewers who approved its reference in the annual editorial)

Aleksandar Cvetkovikj
Ali Serhan Tarkan
Cinzia Centelleghe
Damir Valić
Daniel Matulić
Dragana Milošević
Fabio Madau
Frane Škeljo
Irella Bogut
Ivana Maguire
Ivana Miletić
Ivančica Ternjej
Jonathan Gardner
Josipa Ferri
Luca Mulazzani
Marina Piria
Merica Slišković

Mirela Petrić

Mirela Sertić Perić

Neven Iveša

Predrag Ivanković

Predrag Simonović

Renata Matoničkin Kepčija

Romdhani Ahlem

Şerife Gülsün Kırankaya

Stabińska Agnieszka

Stoimir Kolarević

Tanja Šegvić Bubić

Tea Tomljanović

Thomas Abeel

Tibor Janči

Tomislav Treer

Zoran Marčić

Zrinka Knezović 